\title{
Cikkismertetés: A gazdaságpolitika népegészségügyi hatása - szisztematikus szakirodalmi áttekintés
}

\author{
Article review: Impact of Political Economy on Population Health - \\ a systematic review
}

Ismertető: $\quad$ Vitrai József $\bowtie$

\begin{abstract}
Ismertetett cikk: McCartney G, Hearty W, Arnot J, Popham F, Cumbers A, McMaster R. Impact of Political Economy on Population Health: A Systematic Review of Reviews. Am J Public Health. 2019;109:e1-e12. doi:10.2105/AJPH.2019.305001
\end{abstract}

Beküldve: 2020. 09. 12.

doi: $\quad$ 10.24365/ef.v61i4.636

Kulcsszavak: gazdaságpolitika; népegészségügy; hatás; szisztematikus áttekintés

Keywords: political economy; public health; impact; systematic review

\section{HÁTTÉR}

Noha számos közlemény vizsgálta a gazdaságpolitikának az egészségre kifejtett hatását, annak mértéke és mechanizmusa csupán részlegesen feltárt.

\section{CÉLKITŰZÉS}

Szisztematikusan megkeresni és áttekinteni azokat a közleményeket, amelyek a gazdaságpolitika és a népesség egészségének összefüggését tárgyalják.

\section{KERESÉSI MÓDSZEREK}

A cikk szerzői a Google Scholaron keresztül szisztematikusan keresték a MEDLINE, az Embase, a Társadalomtudomány Nemzetközi Bibliográfiája, a ProQuest Népegészségügy, a Szociológiai Összefoglalók, az Alkalmazott Társadalomtudományi Index és Összefoglalók, az EconLit, a SocINDEX, a Web of Science adatbázisokban, valamint a „szürke” szakirodalomban 2017 májusában fellelhető áttekintő közleményeket.

\section{KIVÁLASZTÁSI KRITÉRIUMOK}

Olyan áttekintő tanulmányokat vontak be, melyek a szakpolitikák, a törvények vagy egyéb jogszabályok, a gazdasági feltételek, az intézmények vagy társadalmi struktúrák, vagy politika és hatalom vagy különböző társadalmi-politikai konfliktusok hatásait elemezték. A kiválasztott cikkekben az egészségre kifejtett hatást az egészség általános mérőszámai, mint például az önértékelt egészségi állapot, a halálozás, a várható élettartam, a túlélés, a jóllét, a megbetegedések, a rossz egészségi állapot és az élethossz jelezte. Két szerző egymástól függetlenül vizsgálta át az összes cikket az előzőekben felsorolt szempontok alapján.

\section{ADATGYŰJTÉS ÉS ELEMZÉS}

Valamennyi bevont közlemény kritikai értékelését a módosított AMSTAR (Assessing the Methodological Quality of Systematic Reviews) kritériumok alkalmazásával végezték. A következtetések levonásakor nagyobb hangsúlyt fektettek a magasabb minőségú cikkekre. 


\section{FŐBB EREDMÉNYEK}

A keresés eredményeként kapott 4912 cikkből 58 áttekintés felelt meg a kiválasztási kritériumoknak, és került elemzésre. Mind az elemzett áttekintések, mind az azokban áttekintett tanulmányok minősége eltérő volt. A szociáldemokrata jóléti államok, a magasabb közkiadások, a tisztességes kereskedelempolitika, a széleskörű kötelező oktatás, a mikrofinanszírozási kezdeményezések az alacsony jövedelmű országokban, az egészségügyi és biztonságossági szakpolitikák, az egészségügyi ellátáshoz való jobb hozzáférés és a jó minőségű, megfizethető lakhatás pozitív hatással van a lakosság egészségére. Úgy tûnik, hogy a politikai rendszereknek az egészségegyenlőtlenségek növekedésével és a magasabb jövedelmi egyenlőtlenséggel járó neoliberális átalakítása a népességben alacsonyabb önértékelt egészségi állapotot és magasabb halálozást eredményez.

\section{SZERZŐK KÖVETKEZTETÉSEI}

A politika, a gazdaság és a közpolitika a népesség egészségének fontos, meghatározó tényezői. A szociáldemokrata rendszerrel, magasabb közkiadásokkal és alacsonyabb jövedelmi egyenlőtlenségekkel rendelkező országokban a népesség egészsége jobb. Komoly hiányosságok mutatkoznak a gazdaságpolitikai viszonyok és az egészség közötti kapcsolat bizonyítékaiban, emiatt magasabb minőségú áttekintésekre és vizsgálatokra van szükség. Ugyan- akkor az ismertetett szisztematikus áttekintés eredményeinek alkalmazásával a lakosság egészségére nézve jelentős kedvező hatást lehet elérni.

\section{NÉPEGÉSZSÉGÜGYRE VONATKOZÓ KÖVETKEZTETÉSEK}

A döntéshozóknak tisztában kell lenniük azzal, hogy a szociáldemokrata jóléti államokban, valamint azokban az országokban, amelyek többet költenek a közszolgáltatásokra, és alacsonyabbak a jövedelmi egyenlőtlenségek, ott jobb az önértékelt egészség és alacsonyabb a halálozás. A kutatás finanszírozóinak és maguknak a kutatóknak is tisztában kell lenniük azzal, hogy továbbra is jelentős hiányosságok tapasztalhatók a rendelkezésre álló bizonyítékokban. Az egyik ilyen terület a kormányzás, a politikák, a hatalom, a gazdaságpolitika, a közpolitika, valamint a lakosság egészsége közötti összefüggések. Vizsgálni szükséges továbbá, hogy a gazdaságpolitika miként formálja a társadalmi folyamatokat és a diszkrimináció megjelenését. Ide tartozik még a tulajdon (a föld és a tőke) megoszlásának és az adópolitikák hatása is. Egyes területeken csupán rosszabb minőségű tanulmányok találhatók, amelyek bizonytalanságot hagynak a gazdaságpolitika és a lakosság egészsége közötti összefüggések természetére nézve. Vannak olyan területek is, ahol a rendelkezésre álló áttekintések olyan kutatási hiányosságokat azonosítottak, mint például a lakáspolitika és lakáshelyzet egészségre gyakorolt hatása.

\section{TANULSÁGOK A HAZAI SZAKEMBEREK SZÁMÁRA}

Ez a közlemény is felhívja a figyelmet, hogy csupán az egyénre fókuszáló népegészségügyi beavatkozások, mint pl. a testsúlykontroll vagy dohányzásleszokás-támogató programok, önmagukban hosszabb távon nem lehetnek sikeresek. Az egészséget és az egészségmagatartást ugyanis közösségszintű tényezők is befolyásolják, azokra is hatni kell, ha fenntartható, népességszintű eredményt akarunk elérni. Az ismertetett cikk meggyőző bizonyítékokat szolgáltat arra vonatkozóan, hogy egy ország gazdasági viszonyai az egészségre jelentékeny hatással vannak. Ismét levonható a következtetés: a népegészségügy csak más szektorokkal együttmúködve lehet sikeres a népesség egészségének javításában. 